\title{
PENGEMBANGAN DESA WISATA PINGE, KECAMATAN MARGA, KABUPATEN TABANAN, BALI
}

\author{
I M. Mega ${ }^{1}$, N.W. Suartini ${ }^{2}$, N.N.C. Kusumawati ${ }^{3}$, dan N.L.R. Purnawan ${ }^{4}$
}

\begin{abstract}
ABSTRAK
Kegiatan pengabdian kepada masyarakat ini bertujuan untuk mengembangkan Desa wisata Pinge, Kecamatan Marga, Kabupaten Tabanan. Metode yang diterapkan dalam pemberdayaan masyarakat pada kegiatan ipteks bagi wilayah ini adalah sebagai berikut: (1) Koordinasi dan komunikasi secara partisipasif dengan desa adat/pengelola desa wisata Pinge untuk merumuskan program mulai dari perencanaan, operasional dan evaluasi; (2) Pemetaan jalur tracking untuk perlintasan wisatawan berjalan-jalan menikmati alam perdesaan dilengkapi viewing deck/balai bengong.; 3) peningkatan kompetensi masyarakat dalam pemandu wisatawan dan ketrampilan berbahasa asing (Inggris); 4) Pengembangan ketrampilan masyarakat dalam pengemasan paket wisata kuliner ditunjang oleh kebun tanaman rempah/bumbu; 5) merekontruksi gerakan tari dan koreografi pertunjukkan bumbung gebyog; 6) Pendampingan yaitu pertemuan secara berkala dan berkelanjutan antara pendamping dengan masyarakat sasaran hingga ipteks yang dialihkan dapat dilaksanakan secara mandiri oleh masyarakat. Hasil yang diperoleh adalah : 1) Jalur trekking di sepanjang lahan persawahan sebagai perlintasan bagi wisatawan berkeliling areal sawah yang dilengkapi dengan tempat pemberhentian (bale bengong) untuk menikmati pemandangan dan hidangan; 2) Sebanyak 10 orang warga desa ( Kelompok Sadar Wisata) telah menguasai teknik memandu dan pelayanan prima kepada wisatawan serta trampil menggunakan bahasa inggris; 3) Telah terbentuknya kelompok wanita tani pengolah pangan lokal/masakan tradisional sebagai hidangan bagi wisatawan dan paket edukasi cocking lesson; 4) terekontruksinya tarian bumbung gebyog sebagai tarian tradisonal yang menarik bagi wisatawan.
\end{abstract}

Kata Kunci : ipteks, pengembangan desa wisata Pinge.

\begin{abstract}
Community service is aimed to develop Pinge Tourism Village, Marga Subdistrict, Tabanan Regency. The methods employed in empowering communities in science and technology activities for the region are as follows: (1) Participatory coordination and communication with indigenous villages / managers of Pinge tourist villages to formulate programs ranging from planning, operations and evaluation; (2) Mapping of tracking tracks for travelers passing a walk to enjoy the nature of the countryside with viewing deck / balai bengong; 3 ) improvement of community competence in tourist guides and foreign language skills (English); 4) Development of community skills in packing culinary tour packages supported by spice plantation / spice garden; 5) reconstruct dance and choreographic movements of gebyog performances; 6) Assistance is regular and ongoing meetings between assistants and target communities to transferred science and technology can be implemented independently by the community. The results obtained are: 1) Tracking tracks along rice fields as a crossing for tourists around the rice field area equipped with a stopping place (bale bengong) to enjoy the scenery and dishes; 2) A total of 10 villagers (Group Sadar Wisata) have mastered the technique of guiding and excellent service to tourists and skilled use of English language; 3) The formation of local
\end{abstract}

\footnotetext{
${ }^{1}$ Staf Pengajar Fakultas Pertanian Universitas Udayana, mega_made@yahoo.com

${ }^{2}$ Staf Pengajar ISI Denpasar

${ }^{3}$ Staf Pengajar Fakultas Peternakan Universitas Udayana

${ }^{4}$ Staf Pengajar FISIP Universitas Udayana
} 
women's food processing group / traditional cuisine as a dish for tourists and cocking lesson education package; 4) reconstructed of gebyog bamboo dance as a traditional dance that appeals to tourists.

Key words : Science, development of Pinge tourism village

\section{PENDAHULUAN}

Desa wisata adalah suatu bentuk integrasi antara atraksi, akomodasi dan fasilitas pendukung yang disajikan dalam suatu struktur kehidupan masyarakat yang menyatu dengan tata cara dan tradisi yang berlaku. ( Nuryanti, Wiendu. 1993). Konsepsi desa wisata adalah menata dan menyediakan sarana penunjang sehingga sebuah desa menjadi destinasi wisata. Wisatawan dapat menginap dan mengikuti aktivitas masyarakat setempat, menikmati kuliner hasil produk lokal serta atraksi budaya seperti kerajinan dan pertunjukan kesenian. Masyarakat desa, tidak hanya sebagai objek melainkan sebagai pengelola dan pelaku dari berbagai komponen yang terintegrasi dalam sistem desa wisata tersebut. Misalnya desa adat berfungsi sebagai pengelolaan objek wisata, sementara masyarakat berperan serta sebagai penyedia jasa dan fasilitas seperti homestay di rumah penduduk, jalur tracking di lahan perkebunan, guide lokal oleh pemuda desa, dan kuliner oleh ibu-ibu PKK. Terdapat dua konsep yang utama dalam komponen desa wisata: 1) Akomodasi : sebagian dari tempat tinggal para penduduk setempat dan atau unit-unit yang berkembang atas konsep tempat tinggal penduduk, 2). Atraksi : seluruh kehidupan keseharian penduduk setempat beserta setting fisik lokasi desa yang memungkinkan berintegrasinya wisatawan sebagai partisipasi aktif seperti : kursus tari, bahasa dan lain-lain yang spesifik (Anon., 2017)

Desa wisata Pinge terletak di Desa Pekraman Pinge, Desa Baru, Kecamatan Marga kabupaten Tabanan, berada diketinggian 500 meter diatas permukaan laut (BPS Kabupaten Tabanan, 2016). Desa tersebut berjarak $17 \mathrm{~km}$ arah utara kota Tabanan (Anon., 2015). Desa wisata Pinge dengan suasana alam pedesaan yang masih asri dan sejuk didukung oleh budaya agraris masyarakat sungguh mencerminkan kehidupan masyarakat Bali yang masih asli. Hanya saja potensi tersebut belum dikelola secara memadai sesuai standar sebuah destinasi wisata. Misalnya pengemasan aktivitas bertani dan tradisi subak serta aktivitas panen produk buah-buahan yang dapat dinikmati langsung menjadi paket wisata menjadi salah satu ragam wisata yang dapat dikembangkan.

Di Desa Wisata Pinge sudah dirintis wisata pedesaan dengan menyediakan paket wisata desa dengan mengajak wisatawan menginap satu bulan di desa tersebut. Wisatawan dapat mengikuti berbagai aktivitas keseharian masyarakat desa dan menginap di rumah-rumah penduduk. Berdasarkan hasil pengamatan awal tidak kurang dari 15 orang wisatawan tinggal di desa tersebut setiap bulan secara bergantian. Namun demikian, kegiatan ini belum memberikan manfaat yang optimal bagi masyarakat lokal karena sebagaian besar kegiatan wisatawan tersebut dilayani oleh agen perjalanan. Lemahnya kemampuan sumberdaya masyarakat khususnya masyarakat adat dalam mengelola sumberdaya kepariwisataan menjadi kendala utama. Pendampingan ketrampilan hospitality (pelayanan prima) dan kemampuan berbahasa asing bagi masyarakat sangat diperlukan.

Potensi seni budaya masyarakat yang sangat diminati oleh wisatawan belum dikelola secara memadai menjadi seni pertunjukkan yang layak dikemas menjadi paket wisata. Kesenian lokal masyarakat saat ini terbatas dipentaskan untuk keperluan ritual atau oleh masyarakat Bali dikenal sebagai "bebalian".Pengenalan Ipteks dalam penciptaan koreografi dalam mengemas kesenian tradisional/sakral menjadi seni provan/pertunjukan dapat menjadikan senibudaya masyarakat menjadi usaha penunjang pariwisata yang bernilai ekonomi tinggi. Selain itu, pengembangan jaringan kemitraan pemasaran paket wisata "Desa Wisata" menjadi bagian penting dari keberhasilan program ini, mengingat mobilisasi wisatawan sangat ditentukan oleh agen perjalanan wisata dan guide. 
Usaha tani merupakan bidang usaha di hulu diharapkan dapat menstimulasi dan menumbuhkembangkan bidang jasa dan usaha lainnya di hilir. Salah satu alternatif adalah berkembangnya industri rumah tangga pengolahan hasil pertanian, pemasaran, dan koperasi yang pada akhirnya dapat memberikan nilai tambah pendapatan bagi masyarakat perdesaan. Kelembagaan tradisional petani yaitu subak masih sangat efektif, begitu pula ketersediaan lahan pertanian masih sangat luas.

\section{METODE PELAKSANAAN}

Metode yang diterapkan dalam pemberdayaan masyarakat pada kegiatan Ipteks bagi Wilayah adalah sebagai berikut: (1) Koordinasi dan komunikasi secara partisipasif dengan kelompok tani masyarakat untuk merumuskan program mulai dari perencanaan, operasional dan evaluasi; (2) Penyuluhan untuk membangun persepsi dan pemahaman masyarakat mengenai inovasi atau program yang diterapkan; (3) Pelatihan dan simulasi mengenai terapan ipeks yang dialihkan bagi masyarakat; (4) Pendampingan yaitu pertemuan secara berkala dan berkelanjutan antara pendamping dengan masyarakat sasaran hingga ipteks yang dialihkan dapat dilaksanakan secara mandiri oleh masyarakat. Adapun kegiatan yang dilaksanakan untuk mengembangkan desa wisata ini adalah : a) Penguatan badan pengelola Desa wisata yang berimplikasi terhadap perkembangan desa wisata; b) Pemetaan jalur tracking untuk perlintasan wisatawan berjalan-jalan menikmati alam perdesaan dilengkapi viewing deck/balai bengong; c) peningkatan kompetensi masyarakat dalam pemandu wisatawan dan ketrampilan berbahasa asing (Inggris); d) Pengembangan ketrampilan masyarakat dalam pengemasan paket wisata kuliner ditunjang oleh kebun tanaman rempah/bumbu; e) Rekontruksi Kesenian tradisional menjadi seni pertunjukan untuk menunjang paket wisata.

\section{HASIL DAN PEMBAHASAN}

Kegiatan Ipteks bagi Wilayah Desa Wisata Pinge dan Bringkit yang telah berlangsung selama 2 tahun ini dalam rangka mengembangkan Desa Wisata Pinge telah dihasilkan beberapa sarana, prasarana dan ketrampilan yaitu :

1) Tersedianya software sistem informasi manajemen desa wisata, dimana software tersebut dapat digunakan untuk memasukkan data, mengolah data, dan menyimpan data tentang kegiatan pariwisata di desa ini. Melalui pelatihan penggunaan software tersebut, maka pengelola sudah terampil dan bisa mengoperasikan sistem informasi manajemen desa wisata, sehingga kegiatan administrasi dan manajemen desa wisata dapat dikelola dengan lebih baik.

2) Jalur trekking di sepanjang lahan persawahan sebagai perlintasan bagi wisatawan berkeliling di areal sawah untuk menikmati keindahan desa yang dilengkapi dengan tempat pemberhentian berupa balai bengong untuk menikmati pemandangan dan hidangan. Pada bale bengong ini, wisatawan akan menikmati pemandangan sawah serta kegiatan petani berupa : membajak sawah, menanam padi secara tradisional dan kegiatan lainnya, serta wisatawan dihidangkan makanan dan minuman khas daerah Pinge.

3) Sebanyak 10 orang warga desa (anggota Kelompok Sadar Wisata) telah menguasai teknik memandu dan pelayanan prima kepada wisatawan serta trampil menggunakan bahasa inggris. 10 orang tersebut bertugas sebagai Guide lokal yang akan memandu para wisatawan selama berada di Desa Wisata Pinge, baik memandu trekking maupun kegiatan lainnya, namun tidak menutup kemungkinan akan bertambah anak-anak muda yang akan ikut memandu dan belajar berbahasa inggris. 
4) Telah terbentuknya kelompok wanita tani pengolah pangan lokal/masakan tradisional sebagai hidangan bagi wisatawan dan paket edukasi cocking lesson. Kelompok ini bertugas dalam menghidangkan kuliner local/masakan tradisional sebagai hidangan bagi wisatawan dan juga melayani paket edukasi teknik-teknik atau cara memasak makanan tradisional, seperti : betutu ayam atau bebek, jukut ares, lawar bali, kopi khas Pinge, jaja kuliner, dan lain-lainnya. Dalam hal kuliner ini ditunjang dengan adanya kebun tanaman bumbu/rempah-rempah seperti : jahe, kunyit dan bahan rempah lainnya.

5) Terlatihnya penari dan penabuh seni Bumbung Gebyog yang sering ditampilkan sebagai atraksi kesenian penunjang paket wisata desa. Tarian bumbung gebyog merupakan seni tari tradisional yang pada mulanya sering dipentaskan pada upacara keagamaan, namun setelah direkontruksi oleh Tim IbW menjadi kesenian yang sangat menarik bagi wisatawan. Menurut Surya (1986, dalam Ariawan ,2014), mengatakan Gambelan bumbung gebyog merupakan kesenian khas daerah bali bagian barat yaitu daerah tingkat II Jembrana, istilah bumbung gebyog berasal dua kata yaitu dari kata bumbung dan gebyog. Bumbung adalah bamboo yang terdiri dari satu atau beberapa ruas yang pada ujungnya dipotong sedemikian rupa sehingga berlubang dan pada pangkalnya dibiarkan tertutup. Sedangkan gebyog adalah suara yang ditimbulkan oleh instrument bumbung.

Berikut disajikan Gambar atau foto kegiatan IbW di Desa Wisata Pinge.

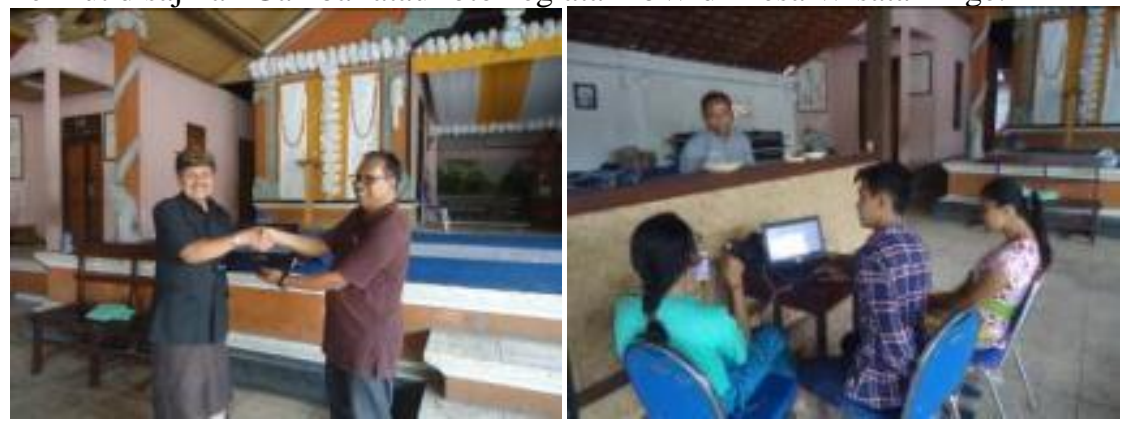

Gambar 1. Penyerahan dan pelatihan penggunaan software system informasi manajemen desa wisata
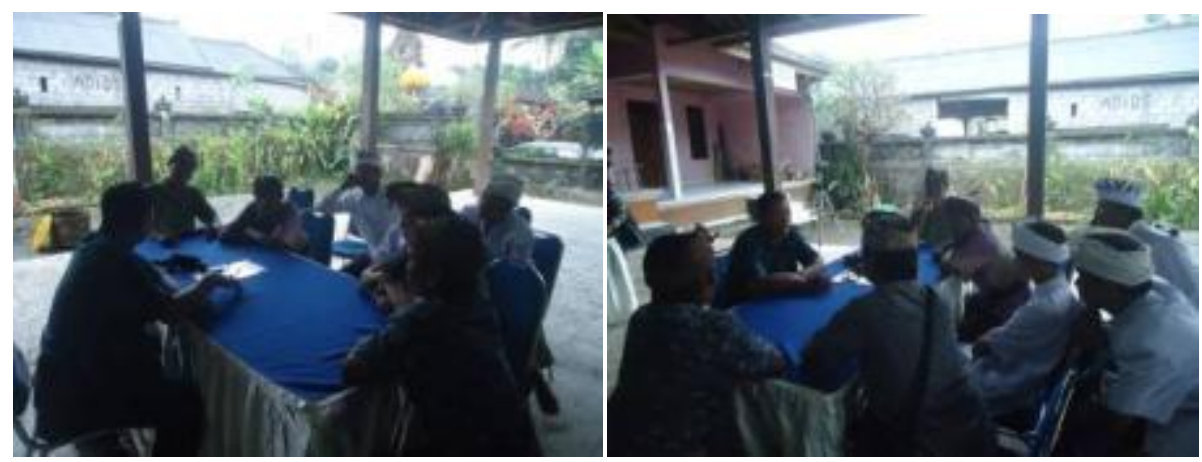

Gambar 2. Pelatihan pelayanan prima dan teknik memandu wisatawan dan berbahasa inggris. 


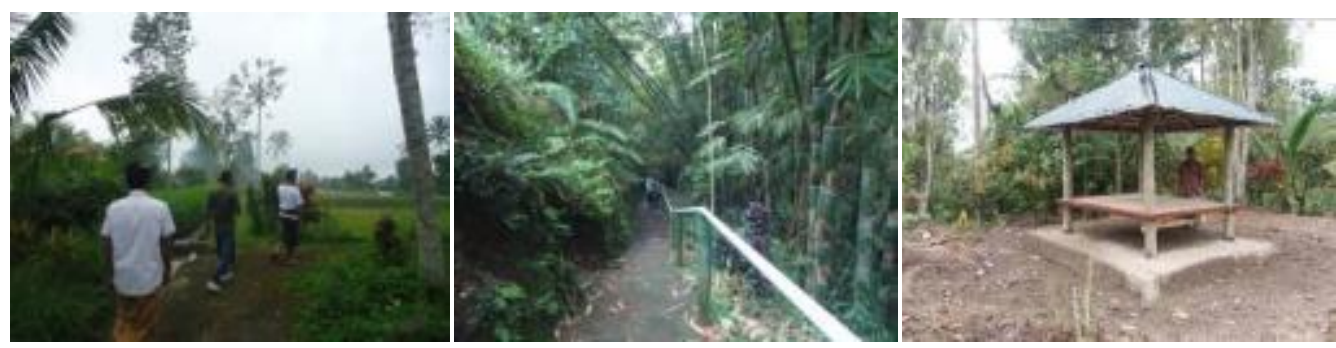

Gambar 3. Jalur trekking dengan balai bengong

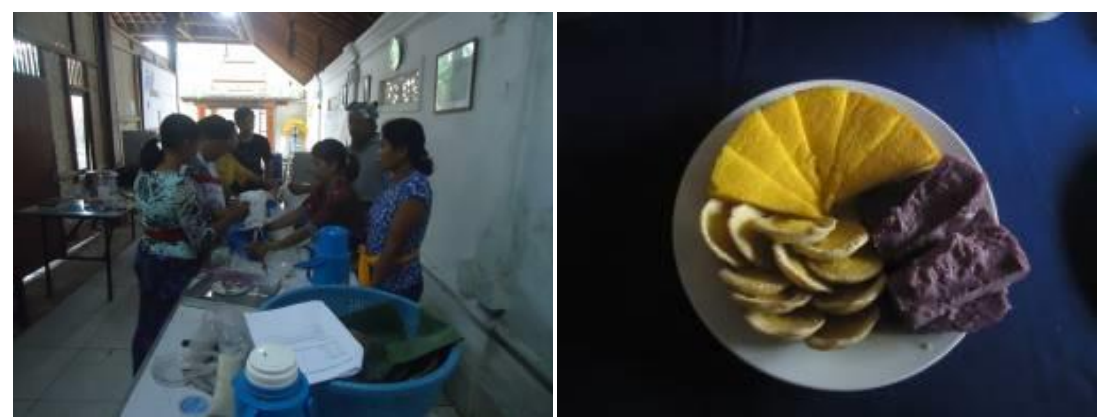

Gambar 4. Pelatihan pembuatan jajan sebagai pelengkap wisata kuliner

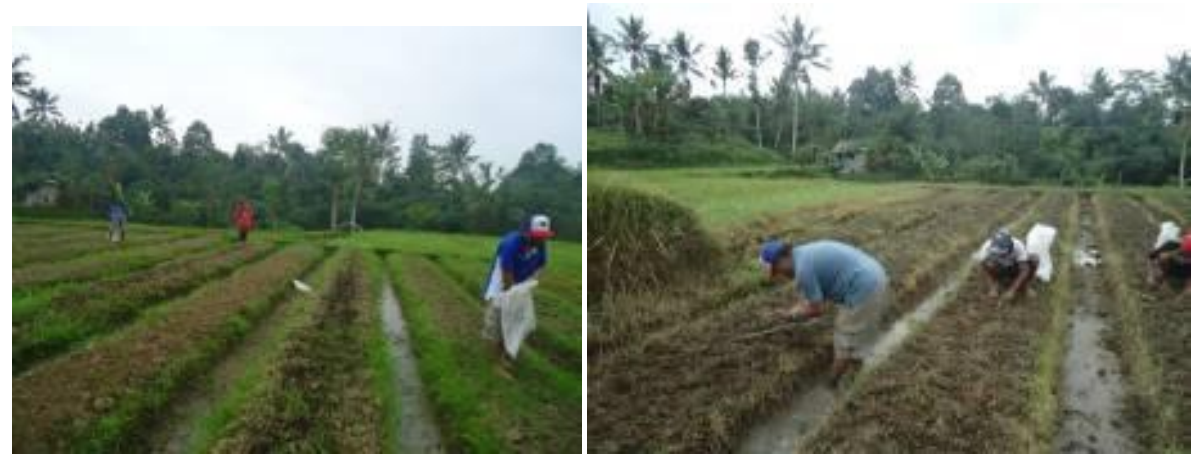

Gambar 5. Pembuatan kebun tanaman bumbu/rempah sebagai penunjang wisata kuliner

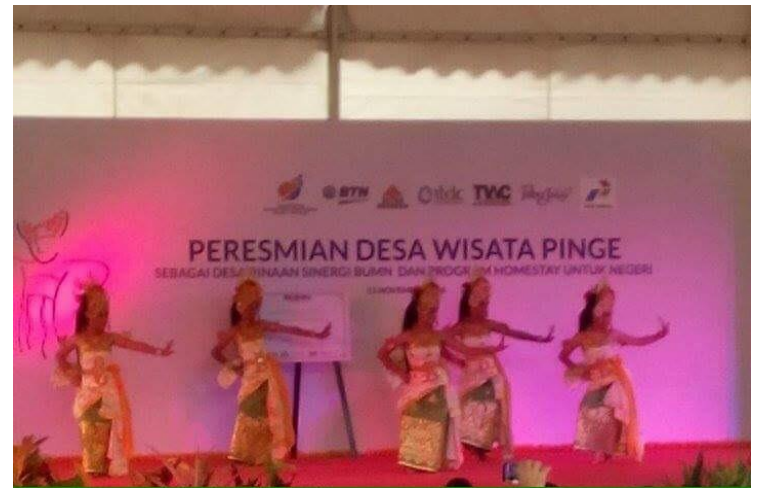

Gambar 6. Seni tari Bumbung Gebyog

\section{KESIMPULAN DAN SARAN}

\subsection{Kesimpulan}

Pelaksanaan program Ipteks bagi Wilayah Desa Pinge dan Bringkit Kecamatan Marga, KabupatenTabanan, Bali dalam rangka pengembangan Desa Wisata Pinge adalah sebagai berikut: 
1. Penguatan kelompok pengelola (kelompok sadar wisata) paket wisata desa yang berimplikasi terhadap perkembangan desa wisata

2. Pemetaan jalur trekking untuk perlintasan wisatawan berjalan-jalan menikmati alam perdesaan dilengkapi viewing deck/balai bengong;

3. Peningkatan kompetensi masyarakat dalam pemandu wisatawan dan ketrampilan berbahasa asing (Inggris);

4. Pengembangan ketrampilan masyarakat dalam pengemasan paket wisata kuliner ditunjang oleh kebun tanaman rempah/bumbu;

5. Rekontruksi kesenian tradisional Bumbung Gebyog menjadi seni pertunjukan untuk menunjang paket wisata.

\subsection{Saran}

Program IbW ini dapat berjalan dengan lancar sebaiknya koordinasi dan komunikasi dilakukan secara intensif antara pemerintah daerah; masyarakat dan stake holder.

\section{UCAPAN TERIMA KASIH}

Penulis mengucapkan terima kasih kepada KEMENRISTEK DIKTI atas dana yang diberikan lewat program Ipteks bagi Wilayah (IbW), Pemda Tabanan, dan Rektor Universitas Udayana, Ketua LPPM Unud beserta staf atas tenaga yang diberikan dalam pelaksanaan di lapangan, sehingga pengabdian kepada masyarakat terlaksana sesuai rencana.

\section{DAFTAR PUSTAKA}

Anonimus. 2015. Monografi Desa Baru, Kecamatan Marga kabupaten Tabanan

Anonimus. 2017. Desa Wisata. https://id.wikipedia.org/wiki/Desa_wisata.

Ariawan, W. 2014. Bumbung Gebyog. Dikutip dari Buku Gambelan Bumbung Gebyog Di Desa Dangin tukad daya Negara, ( Karya : I Made Surya, 1986) • http://blog.isi-dps.ac.id/wayanariawan/tugasmultimedia-artikel-gambelan-bumbung-gebyog

BPS Kabupaten Tabanan. 2016. Tabanan dalam Angka.

Nuryanti, Wiendu. 1993. Concept, Perspective and Challenges, makalah bagian dari Laporan Konferensi Internasional mengenai Pariwisata Budaya. Yogyakarta: Gadjah Mada University Press. Hal. 2-3) 